\title{
PENANGGULANGAN ALIRAN BERMASALAH DI MAN MODEL TERNATE
}

\section{Preventing the Spread of Unacceptable Religious Faith in MAN Model Ternate}

\author{
M. Sofyan BR \\ Balai Penelitian dan Pengembangan Agama Makassar \\ Jl. A.P. Pettarani No. 72 Makassar \\ email: sofyan_litbang@yahoo.com
}

Naskah diterima tanggal 1 Juli 2014. Naskah direvisi tanggal 25 Juli 2014. Naskah disetujui tanggal 6 Agustus 2014

\begin{abstract}
Abstrak
Penelitian ini bertujuan untuk mendeskripsikan upaya madrasah terhadap penanggulangan aliran keagamaan yang ditengarai sebagai aliran bermasalah menurut perspektif masyarakat setempat. Penanggulangan yang dilakukan oleh madrasah dicermati melalui wawacara, observasi, dan studi dokumentasi terhadap upaya yang dilakukan madrasah, baik melalui dokumen pembelajaran, kegiatan pembelajaran, ataupun kegiatan tambahan dalam berbagai bentuk. Hasil penelitian menunjukkan, dominan penanggulangan dilakukan dalam bentuk pencegahan untuk menghindarkan siswa terlibat dalam aliran bermasalah. Kegiatan pencegahan juga melibatkan pihak luar madrasah.
\end{abstract}

Kata kunci: madrasah, Ternate, aliran bermasalah, penanggulangan

\begin{abstract}
Abstrak
Research aimed to describe the effort of madrasha to prevent the spread of unacceptable religious teachings based on community perspective in MAN Model Ternate. Research was performed through interview, observation, documentation to learning processes and activity. Research shows that prevention is performed by involving other parties to make it more effective.
\end{abstract}

Key words : madrasah, Ternate, prevention

\section{PENDAHULUAN}

$\mathrm{P}$ endidikan adalah upaya pemanusiawian manusia, bertujuan untuk mencerdaskan kehidupan bangsa dan mengembangkan manusia Indonesia seutuhnya, yaitu manusia yang beriman dan bertuhan terhadap Tuhan Yang Maha Esa dan berbudi pekerti luhur, memiliki pengetahuan dan keterampilan, kesehatan jasmani dan rohani, kepribadian yang mantap dan mandiri serta rasa tanggung jawab kemasyarakatan dan kebangsaan. (Darmayati Zuchdi, 2009:97). Sedangkan pendidikan agama adalah "pendidikan yang memberikan pengetahuan dan membentuk sikap, kepribadian, dan keterampilan peserta didik dalam mengamalkan ajaran agamanya, yang dilaksanakan sekurang-kurangnya melalui mata pelajaran/kuliah pada semua jalur, jenjang dan jenis pendidikan." (PP. No. 55 Tahun 2007, Bab I pasal 1 ayat (1).

Kementerian Agama yang memiliki tusi pembinaan umat beragama, memandang aliran bermasalah urgen untuk ditangani. Salah satu langkah konkrit yang dilakukan adalah menerbitkan "Buku Panduan Penanganan Aliran dan Gerakan Keagamaan Bermasalah di Indonesia" sebagai salah satu pedoman pembinaan. Madrasah sebagai salah satu lembaga pembina komunitas belajar, seyogyanya mengapresiasi keprihatinan nasional tersebut untuk dilakukan di satuan pendidikan bersangkutan. 
Fenomena aliran bermasalah bukanlah hal baru dalam Islam. Sepeninggal Nabi Muhammad, muncul kelompok-kelompok yang menyempal dari ajaran pokok Islam misalnya Muzailama Al Kazzab yang mengklaim diri sebagai nabi baru, kelompok Zindiq dari Persia semisal Ibnu Ar Rawandi yang mengkritik konsep kenabian Nabi Muhammad dan syariat yang diajarkan, dan Muhammad bin Zakaria bin Ar-Razy menolak seluruh kenabian Muhammad.

Untuk konteks Indonesia, beberapa nalar yang menyempal dari ajaran pokok Islam juga muncul, misalnya Syekh Siti Jenar yang mengajarkan teologi penyatuan antara manusia dan Tuhan (manunggaling kawula Gusti). Pasca reformasi, beberapa aliran bermasalah dari revitalisasi Ahmadiyah, Lia Eden, Al Qiyadah Al Islamiyah, Quran Suci, Satrio Paningit, Shalat Dwi Bahasa Yusman Roy, Aliran kebatinan ala Mahdi, dan An Nazir. Di Sulawesi Barat misalnya shalat bersiul Sumardi, Puang Malea, dan Sando Buta; di Sulawesi Selatan Paruru, di Sulawesi Utara Ali Teitan. Mungkin masih banyak lagi di belahan bumi Indonesia lainnya.

Hasil jajak pendapat yang dilakukan Republika terhadap 1227 responden, mengungkapkan lima pemicu, dominan munculnya kelompok-kelompok bermasalah, yaitu Pertama, para ulama yang sibuk dengan urusan dunianya.Kedua, penyusupanagenda asing. Ketiga, kemiskinan dan keterbelakangan ummat. Keempat, semakin minimnya pendidikan agama, dan yang kelima metode dakwah yang kurang menarik. (Abdurrahman Mas'ud, Dialog No. 68: 2007:17). Menyangkut metode dakwah, menurut Aqiel Siraj disampaikan secara monoton dan kurang mendalam. Bahkan isinya tidak lagi berifat mengajak tetapi lebih terkesan memprovokasi sehingga mudah sekali memunculkan kebencian di kalangan umat. Akibatnya, Islam tampil sebagai rumah yang tidak ramah dan membuat sebagian umat Islam merasa jenuh dan akhirnya mencari ikatan persaudaraan keagamaan yang lebih nyaman. Disinilah aliran bermasalah mengambil peran.

Beberapa penelitian terkait yang pernah dilakukan oleh peneliti Balai Litbang Agama Makassar: Penelitian tentang aliran patuntung di Sulawesi Selatan, seperti Ammatoa di Kajang, Aluk Todolo di Toraja dan Towani Tolotang di Sidenreng Rappang (Sidrap); Persepsi siswa terhadap tindak kekerasan atas nama agama; Varian keagamaan terhadap berbagai aliran dan faham keagamaan; Juga penelitian tentang aliran bermasalah, misalnya: Aliran sesat Sando Buta oleh Husnul Fahima di Polman (2011), Awaluddin Ma'rifatullah wa Ma'rifaturrasul di Samarinda oleh Abd. Shadiq Kawu (2011), dan Paruru di Makassar, oleh Saprillah (2011). Penelitian-penelitian tersebut banyak dilakukan pada komunitas tertentu dalam masyarakat.

Penyebaran aliran bermasalah sudah menyentuh mahasiswa dan siswa (Haidar Bagir, 2012). Bahkan, Rektor UII Prof. Dr. Edi Suandi Hamid, M.Ec, menyatakan bahwa mahasiswa/ pelajar adalah populasi yang cukup besar terlibat aliran bermasalah. Mereka mudah tertarik terhadap pilihan-pilihan yang mudah dijalani. Suka mencari hal-hal yang baru, lalu disikapinya sebagai sesuatu yang positif. Karenanya aliran sesat (penbermasalah) menjadi pilihan mereka karena mudah dijalani.

Peserta didik pada satuan pendidikan madrasah adalah kelompok usia yang sedang bertumbuh dan berkembang, sedang mencari bentuk dan jati dirinya. Bila faham bermasalah menjadi bagian yang mengisi jiwanya, maka tidak mustahil faham bermasalah dan ajarannya mewarnai sikap dan perilakunya. Madrasah sebagai lembaga yang memiliki tugas dan fungsi edukatif, berperan dalam memberikan arah terhadap perkembangan kepribadian siswa termasuk kehidupan keagamaannya, dengan memperkuat pemahaman dan pengaplikasian nilai-nilai agama yang esensial, sambil memproteksi siswa dari nilai dan ajaran yang menyempal dari Islam.

Untuk mengetahui upaya yang dilakukan oleh madrasah, terhadap hal tersebut, maka dilakukan penelitian tentang penanggulangan penyebaran aliran bermasalah di Madrasah. Penelitian ini dilakukan di Ternate Maluku Utara. Penelitian mengidentifikasi langkah penanggulangan yang dilakukan oleh madrasah sehingga diperoleh informasi awal mengenai pola-pola penanggulangan aliran bermasalah di madrasah yang diteliti. Informasi penelitian dapat menjadi masukan dalam penyusunan pola penanggulangan aliran bermasalah di madrasah secara luas. 
Secara sederhana, penelitian ini menjadikan informan sebagai subjek penelitian dalam konteks kesehariannya, mencakup fenomena yang mengitarinya serta nilai-nilai yang dianutnya. (Muhajir, 1994: 97-98), menyarankan bahwa penelitian berlandaskan fenomenologi hendaknya memahami empat kebenaran "emik" yaitu kebenaran empiris terindra, kebenaran empiris yang logis, kebenaran empiris etik, dan kebenaran transendental. Aspek pengetahuan itu dilihat dalam 4 kategori, yaitu: (a) Pengetahuan indria, yakni pemahaman yang didasarkan pada tangkapan indrawi, seperti pendengaran, penglihatan, penciuman. rasa terhadap aliran bermasalah itu; (b) Pengetahuan etik, yaitu pemahaman yang didasarkan pada baik buruknya yang dipersepsikan pada aliran bermasalah; (c) Pengetahuan logis, yakni pemahaman yang disertai nalar, analisis yang biasanya mengacu pada manfaat-mudharat, untung-rugi, serta masuk akal atau tidak; dan (d) Pengetahuan transendental, yakni pemahaman yang didasarkan pada nilai dan dasar agama yang mengacu pada baik-tidaknya, halal-haramnya, benar-salahnya dan aspek-aspek yang fundamental lainnya.

Ada tujuh tipe sekte atau gerakan bermasalah yang dikemukakan. Pertama, convensionist, yang mengarahkan perhatiannya kepada perbaikan moral individu dengan kegiatan utamanya mentobatkan orang luar. Kedua, "revolusioner", yakni gerakan yang mengharapkan perubahan masyarakat secara radikal, misalnya gerakan messianistik. Ketiga, "introversionis", kelompok yang mencari kesucian diri sendiri tanpa mempedulikan masyarakat luas. Keempat, "manipulationis" atau Gnostic (berma'rifat), yaitu gerakan bermasalah yang senderung tidak peduli terhadap keselamatan dunia sekitar. Kelima, "thaumaturgical", yakni gerakan bermasalan yang mengembangkan system pengobatan, pengembangan tenaga dalam atau penguasaa alam gaib. Keenam, "reformis", yakni gerakan yang melihat usaha reformis sosial sebagai kewajiban esensial agama. Ketujuh, "Utopian", yakni suatu gerakan sekte yang berusaha menciptakan suatu komunitas ideal sebagai teladan masyarakat luas (Nunu Burhanuddin, 2012).

Untuk menentukan yang bermasalah, terlebih dahulu harus dipahami yang mainstream. Menurut
Martin Van Bruinessen, untuk kasus umat Islam Indonesia yang ortodoks atau mainstream adalah aliran induk yang diwakili oleh lembaga keagamaan seperti MUI, Muhammadiyah dan Nahdlatul Ulama. Penilaian bermasalah atau tidak terhadap suatu aliran, sangat tergantung pada apa kata ajaran induk yang menjadi mainstream (Martin Van Bruinessen, 1992:16-17). Jika yang dimaksudkan dengan aliran induk mainstream adalah Ahlussunnah wal Jamaah yang dianut oleh lembaga keagamaan tersebut, maka yang menyimpang dari Ahlussunnah wal Jamaah merupakan bermasalah dan sesat.

Melihat gerakan dan paham-paham keagamaan yang sering suatu saat sebagai mainstream dan saat lain menjadi bermasalah, begitupun sebaliknya, maka Bruinessen melihatnya sebagai kriteria sosiologis. (Nunu Burhanuddin, 2012). Dengan perspektif ini, maka penelitian tidak hanya melihat eksistensi aliran bermasalah yang dibangun berdasarkan konsep, tetapi juga yang dipahami oleh masyarakat sasaran. Hal itu penting dilakukan karena merupakan bagian dari data emik yang menjadi aspek penting dalam penelitian kualitatif sebagaimana penelitian ini.

Berkaitan dengan upaya-upaya madrasah dalam penanggulangan aliran bermasalah yang menjadi topik penelitian ini, landasan teoritik penelitian didasarkan pada teori tentang sikap dan perilaku sosial, khususnya Teori Keinginan Berprilaku (Theory of Behavior Intentions) yang dirumuskan oleh Martin Fishbein (1972) (Masri Singarimbun dkk., 1987:38) yakni: keinginan berprilaku ditentukan secara bersama-sama oleh persepsi tentang manfaat perilaku tersebut dan persepsi tentang sikap kelompok referensi terhadap perilaku tersebut.

Urgensi penelitian ini merupakan implementasi dari arah kebijakan dan strategi Kementerian Agama dalam upaya meminimalisir aliran bermasalah dan tindak kekerasan yang mengatasnamakan agama. Juga mendukung arah kebijakan Badan Litbang Agama dalam hal penyediaan data dan informasi; rumusan rekomendasi, pokok pikiran pengembangan, dan bahan/draft kebijakan berbasis hasil penelitian bidang pendidikan agama dan keagamaan dalam rangka mendukung perumusan kebijakan pimpinan dan unit-unit teknis Kementerian Agama 
(Badan Litbang dan Diklat Kementerian Agama RI, 2010:33).

Berdasarkan pada latar belakang di atas, permasalahan yang diangkat dalam penelitian ini adalah bagaimana upaya madrasah menanggulangi penyebaran aliran bermasalah bagi siswa-siswanya. Berkaitan masalah pokok tersebut, ditelusuri bagaimana persebaran aliran bermasalah, bagaimana upaya pencegahan madrasah terhadap aliran bermasalah, bagaimana respon masyarakat dan komunitas madrasah terhadap upaya penanggulangan yang dilakukan di madrasah.

Tujuan penelitian adalah untuk mengetahui upaya-upaya madrasah dalam menanggulangi penyebaran aliran bermasalah bagi siswa-siswanya. Untuk memperoleh informasi yang tuntas dan relevan dengan tujuan penelitian tersebut, maka perlu: (a) Mengetahui dan mengidentifikasi keberadaan aliran bermasalah yang ada/pernah ada di lokasi penelitian, (b) Mengetahui upaya-upaya yang dilakukan madrasah untuk mencegah siswanya dari pengaruh aliran bermasalah, (c) Mengetahui respon masyarakat lokasi penelitian terhadap upaya yang dilakukan madrasah dalam penanggulangan aliran bermasalah, dan (d) Mengetahui persepsi komunitas madrasah tentang aliran bermasalah yang ada di lokasi mereka. Selain itu, penelitian ini diharapkan dapat bermanfaat: terhadap madrasah dalam merumuskan pola-pola penanggulangan aliran bermasalah, atau pun terhadap Kementerian Agama untuk penyusunan pola-pola pembinaan madrasah dalam menanggulangi penyebaran aliran bermasalah.

\section{Fokus Penelitian dan Deskripsi Fokus}

Sempalan (bermasalah) dalam bahasa Indonesia, memiliki makna patahan, potongan (kayu). Kemudian dalam bahasa Arab ditemukan tiga konsep sehubungan aliran atau pemahaman terhadap Islam, yaitu mahzab, firqah dan zindiq. Firqah dari kata "faraqa" berarti berpisah atau menyempal melibatkan penganutan lebih kecil. Kemudian kata yang sepadan berarti "keluar dari agama" baik karena akidah maupun praktekpraktek yang bertentangan dengan syariah (http:// id.shnoong.com/social-science/education/2189511, diakses, 06-01-2012). Dengan demikian aliran bermasalah adalah aliran yang berpisah atau memisahkan diri dari Islam mainstream atau dari mahzab-mahzab yang diakui.

Langkah-langkah apresiatif yang dilakukan madrasah yang dicermati dalam penelitian ini, meliputi: (a) Langkah/preventif. Dengan menginspirasi penanggulangan kenakalan remaja, maka upaya preventif terhadap aliran bermasalah adalah upaya sistematis, berencana dan terarah untuk menjaga agar siswa tidak terkontaminasi dengan aliran bermasalah, diantaranya: Pencegahan masuknya aliran bermasalah ke madarah, pencegahan terhadap ikut sertanya siswa dan komunitas madrasah ke dalam aliran bermasalah di luar madrasah, pencegahan terhadap beredarnya brosur, pamplet atau buku-buku aliran bermasalah di madrasah; (b) Langkah refresif. Usaha penindakan madrasah terhadap siswa yang terkontaminasi aliran bermasalah, baik yang tertuang dalam tata tertib maupun bentuk lainnya, misalnya: tersedianya sanksi bagi siswa yang terlibat dalam aliran bermasalah baik langsung maupun tidak langsung; (c) Langkah Kuratif dan Rehabilitasi, yakni upaya pencerahan dan penguatan melalui pembinaan khusus baik oleh internal madrasah, maupun melibatkan lembaga lain di luar madrasah. Misalnya tersedianya wadah pencerahan bagi siswa tentang mudharat aliran bermasalah dalam tatanan kehidupan keagamaan, masyarakat, bangsa dan negara, dalam kurikuler, kokurikuler, atau ekstrakurikuler. Terhadap tiga langkah tersebut, ditelusuri detail aplikasinya melalui wawancara mendalam maupun penelusuran dokumen dan observasi.

Terkait aspek-aspek penyempalan dari aliran bermasalah yang teridentifikasi dapat dikaitkan dengan 10 kriteria aliran bermasalah/sesat yang difatwakan oleh Majelis Ulama Indonesia (MUI), yaitu: mengingkari salah satu rukun Iman atau rukun Islam, meyakini atau mengikuti aqidah yang tidak sesuai dengan dalil syar'i, meyakini turunnya wahyu setelah Al Qur'an, mengingkari keotentikan atau isi kandungan $\mathrm{Al}$ Qur'an, mentafsiri $\mathrm{Al}$ Qur'an tanpa kaidah tafsir, mengingkari Hadits Nabi sebagai sumber Islam, melecehkan atau merendahkan Nabi dan Rasul, mengingkari Nabi Muhammad SAW sebagai nabi terakhir, merubah pokok-pokok yang telah ditetapkan oleh Syari'ah, mengkafirkan sesama muslim tanpa dalil syar'i. 


\section{METODE PENELITIAN}

Penelitian ini berupaya menangkap dan mengungkapkan tentang fenomena sosial keagamaan terkait aliran bermasalah di madrasah yang diteliti. Data yang dihasilkan digambarkan secara sistematis, faktual dan akurat mengenai fakta-fakta dan realitas yang diamati dengan menggunakan pendekatan kualitatif, untuk memahami fenomena tentang apa yang di alami oleh subjek penelitian (Maleong, 2008:6).

Penelitian ini dilakukan di Ternate Maluku Utara, dengan madrasah aliyah sebagai sasaran. Penentuannya dilakukan secara purposive dengan teknik sebagai berikut: (a) Pada lokasi sasaran penelitian. Peneliti memilih satu madrasah aliyah dijadikan sasaran penelitian, berkoordinasi dengan pejabat Kementerian Agama terkait; (b) Sumber pendapat dipilih dari: kalangan madrasah, pejabat terkait dalam jajaran Kementerian Agama provinsi dan kabupaten/kota, tokoh masyarakat dari unsur MUI, tokoh agama Islam setempat, dan pengurus organisasi kesiswaan.

Data yang dikumpulkan, meliputi: data tentang identifikasi dan eksistensi aliran bermasalah, pengetahuan dan pemahaman komunitas madrasah tentang aliran bermasalah, upaya penanganan yang dilakukan oleh madrasah, dan respon komunitas madrasah terhadap upaya penanganan yang dilakukan oleh madrasah bersangkutan. Untuk menjaring data yang diperlukan, dilakukan beberapa teknik, yaitu: data primer dikumpulkan melalui observasi, wawancara mendalam terhadap sumber-sumber pendapat yang relevan. Selain itu, dilakukan studi dokumentasi, yakni penelusuran dan pencatatan terhadap sumber-sumber tertulis pada madrasah yang diteliti, kantor Kemenag Provinsi, Kabupaten/Kota serta instansi terkait lainnya. Juga studi pustaka, yakni kajian literasi terhadap sumber-sumber bacaan yang terkait topik penelitian di lakukan sebelum ataupun sesudah pengumpulan data lapangan, untuk membandingkan apa yang ditemukan dengan apa yang dikatakan dalam kepustakaan professional, konsep, model dan paradigma orang lain dapat pula dimanfaatkan untuk membandingkan hasil penemuan dari data.Terhadap data primer atau sekunder yang diperoleh dari penelitian dilakukan kategorisasi sesuai jenis, sifat data itu sendiri dan dideskripsikan. Data direduksi sesuai item fokus penelitian kemudian dilakukan interpretasi yang menjadi asumsi dasar dalam penyusunan hasil penelitian.

\section{PEMBAHASAN \\ Setting Penelitian}

Kota Ternate sebagai pusat pemerintahan dan perdagangan di Maluku Utara, menjadi area pertemuan masyarakat yang berbeda agama, etnik, budaya dan latar belakang kehidupan sosial. Berbagai organisasi sosial keagamaan Islam seperti NU, Muhammadiyah, Al Khaerat, Hidayatullah, Jamaah Tabligh, Wahdah Islamiyah, HTI, dan lainlain terdapat di sana. Kota Ternate, selain pusat pemerintahan dan perdagangan, juga menjadi pusat pendidikan di Maluku Utara. Sebagai kota pendidikan tersedia sejumlah lembaga pendidikan umum dan agama, mulai jenjang pra sekolah sampai perguruan tinggi. Perguruan Tinggi yang ada, di antaranya STAIN Ternate, UNHAIR dan Unismuh.

Bila dipetawilayahkan wilayah Selatan Kota Ternate, kehidupan sosial keagamaan masyarakatnya cenderung lebih moderat, sedangkan wilayah utara lebih tradisional. Di utara muncul beberapa aliran/faham keagamaan yang dinilai oleh masyarakat menyempal dari faham keagamaan yang dianut secara luas yakni "ahlus sunnah wal jamaah". Aliran/faham keagamaan itu ada yang datang dari luar seperi Ahmadiyah, Syiah Jafariyah. Ada pula yang muncul dari dalam seperti "guru ibu", wongi-wongi dan sebagainya. Di luar wilayah Temate, beberapa faham keagamaan yang dinilai menyempal, di antaranya, aliran $\mathrm{La}$ dan $\mathrm{Lu}$ di Halmahera Utara, aliran Noceh di Morotai dan beberapa daerah lainnya.

Mencermati munculnya aliran bermasalah di Maluku Utara, selain aspek geografis sebagai daerah kepulauan sehingga interaksi penduduk antara pulau tidak terlalu intens, juga faham keagamaan yang mengakar secara sosio kultural dalam masyarakat Maloko Kie Raha. Menurut Gufran A. Ibrahim (Haedar, 2003:186-189), tiga tipologi keberagamaan Maloku Kie Raha, yaitu: (1) Tipologi satu,disimbolkan dengan "JagatAtahadi", yakni sosok yang bersahaja, minim pengetahuan agama,tetapi memiliki kepekaan spiritual sehingga 
dapat mengetahui sesuatu yang belum terjadi tapi enggan ke mesjid; (2) Tipologi dua, digambarkan sebagai "fenomena salasa", pandai mengaji, hafal rukun Islam dan rukun iman, tahu kaifiat shalat, tahu pahala dan dosa, tetapi rajin juga mengamalkan kebaikan dan mengerjakan dosa. Menjadi komunitas yang banyak di masyarakat. enteng dalam pengamalan; (3) Tipologi ketiga, disebutkan The school of Jo Guru" yakni kelompok yang memelihara wacana pembelajaran pada seorang guru. Fatwa guru adalah aksioma yang dipegangi selamanya. Mereka mengembangkan kultur keberagamaan yang memadukan etos dan moralitas lokal dengan ajaran Islam.

\section{Profil MAN Model Ternate}

MAN Model Ternate, awalnya adalah madrasah konvensional, didirikan pada tanggal 16 Maret 1978, berdasarkan Surat Keputusan Menteri Agama RI Nomor 17 Tahun 1978. Seiring penguatan kelembagaan madrasah, beberapa madrasah di seluruh Indonesia diberi penguatan menjadi "madrasah model", maka MAN Ternate menjadi MAN Model sejak tanggal 23 Mei 2003. Sejak didirikan, telah dipimpin oleh beberapa kepala madrasah. Sekarang dipimpin oleh Dra. Hj. Maryam Djama, sejak 1 Maret 2007. MAN Model Ternate telah terakreditasi oleh BAP Maluku Utara Nomor: Ma.000475 tanggal 29 September 2007 dengan peringkat "A" (sangat baik).

Visi MAN Model Ternate adalah "Terwujudnya manusia yang unggul dalam Imtaq, Iptek, dan Populis". Misi MAN Model Temate adalah: Meningkatnya pelaksanaan manajemen partisipasi, mengembangkan keunggulan dalam bidang agama, budaya. ilmu pengetahuan, teknologi, dan keterampilan seluruh komponen madrasah, meningkatkan kedisiplinan dan tanggungjawab stakeholder madrasah, meningkatkan kinerja sumberdaya secara menyeluruh, membina dan mengembangkan kerjasama antara warga madrasah dan masyarakat, melengkapi dan memberdayakan sarana dan prasarana penunjang proses belajar mengajar, mengoptimalkan penghayatan nilai-nilai keagamaan untuk dijadikan sumber kearifan dalam bertindak. (Sumber: MAN Model Ternate, 2012).

MAN Model Ternate dibina oleh 41 orang guru, terdiri atas guru tetap (GT) 38 orang dan gura tidak tetap (GTT) sebanyak 3 orang. Ke 41 orang guru tersebut, 9 orang di antaranya berpendidikan S2 dalam berbagai jurusan, 29 orang lainnya berpendidikan SI. Sedangkan jenjang kepangkatan mereka, satu orang golongan IV/b, 14 orang IV/a, 5 orang IV/d, 8 orang Ill/d, 7 orang lil/c, satu orang III/b, dan 7 orang Ill/a. Kemudiaan GTT sebanyak 3 orang. Terhadap 38 orang guru PNS yang ada, 31 orang telah tersertifikasi, masih ada 7 orang belum tersertifikasi. Sedangkan tenaga kependidikan yang menangani ketatausahaan sebanyak 7 orang, semuanya PNS. Jenjang kepangkatan mereka adalah golongan III/c satu orang, Ill/b satu orang, II/c 2 orang, II/b satu orang, dan II/a 2 orang.

Pada bulan Januari 2012 jumlah siswa MAN Model Ternate tercatat 320 orang. Tahun ini menamatkan 67 orang siswa. Tahun pelajaran 2012/2013 menerima 97 orang siswa. Jumlah siswa sekarang 350 orang, terdiri atas 12 rombongan belajar (rombel). Untuk menjaga keamanan madrasah, terdapat satu orang Security yang hanya bertugas di siang hari. Untuk memelihara kebersihan madrasah, di samping dilakukan oleh siswa, juga menugaskan 2 orang petugas cleaning service yang bertugas setiap hari sekolah.

Untuk mendukung kegiatan pembelajaran, administrasi, pertemuan, dan keperluan lainnya; dari sejumlah gedung yang ada, terdapat 28 ruangan yang diperuntukan sesuai proporsinya, masing-masing: Ruang kelas 12 buah, ruang Kepala Madrasah 1 buah, ruang guru 2 buah, ruang TU 1 buah, ruang lab komputer 1 buah, ruang lab bahasa 1 buah, ruang lab IPA 1 buah, ruang perpustakaan 1 buah Ruang pertemuan/aula 1 buah, WCguru2 buah, WC siswa 3 buah, ruang multimedia 1 buah, Mushalla 1 buah, dan ruang BP/BK 1 buah.

Identifikasi dan Eksistensi Aliran Bermasalah

Mengkategorikan sebuah aliran keagamaan termasuk bermasalah atau tidak, biasanya mengacu pada mainstream keagamaan yang ada. Sebagai penelitian sosial, persepsi masyarakat secara kontekstual menjadi penting dicermati. Terlebih lagi sebagai penelitian kualitatif yang sangat mengedepankan data emik yang digali dari masyarakat. Pengkategorian aliran bermasalah dalam penelitian ini didasarkan pada apa yang dipersepsikan masyarakat. Asumsi ini mengacu pada teori yang dikemukakan oleh Martin Van 
Bruinessen bahwa penelitian aliran bermasalah adalah wilayah kajian sosiologis.

Sejumlah aliran yang dianggap bermasalah di Ternate oleh masyarakat yang dijadikan informan, teridentifikasi beberapa diantaranya:

Aliran Ahmadiyah. Beberapa tahun yang lalu, aliran ini eksis di Temate dan beberapa kabupaten lainnya di Maluku Utara. Di Ternate pernah ada masjid Ahmadiyah. Sejak adanya penyesatan Ahmadiyah oleh MUI, pengikutnya tidak lagi melakukan lagi aktivitas di masjid tersebut, khawatir akan adanya penyerangan dari masyarakat. Ajarannya yang dinilai menyimpang oleh masyarakat diantaranya adalah syahadat mereka yang menyatakan bahwa Mirza Ghulam Ahmad adalah Nabi, mengingkari Nabi Muhammad sebagai nabi terakhir.

Aliran Syiah Ja'fariyah. Aliran ini muncul sekilar tahun 2010 yang lalu dipopulerkan oleh Nawir, salah seorang cucu imam masjid di salah satu masjid di Kelurahan Marikuru Temate Utara. Nawir merekrut beberapa anak muda disekitarnya sebagai pengikutnya. Sebagian dari mereka anak muda yang putus sekolah bahkan ada diantaranya pegawai negeri. Diantara ajarannya adalah tidak sah shalat jamaah bila diimami selain dari penganutnya. Shalat tidak perlu angkat tangan. Melakukan penentangan terhadap jamaah lain di masjid di sekitar tempat tinggal mereka. Akibat kelakuannya itu, masyarakat mengadukannya ke Kementerian Agama dan MUI Kota Ternate. Atas aduan itu diadakanlah dialog melibatkan berbagai unsur. Hasil dialog menegaskan agar pengikut aliran tersebut tidak melakukan aktifitas penyebarannya terhadap masyarakat.

Selain dua aliran bermasalah tersebut, terdapat pula beberapa aliran lokal bermasalah di antaranya: Arsyad Doa, tokohnya bernama Arsyad, diantara ajarannya: shalat lima waktu tidak penting; bila akan shalat tidak perlu terikat akan waktu, tempat dan tata cara; penerimaan ajaran dilakukan secara tertutup di dalam kelambu.

Aliran Noce, di Morotai tokohnya Noce. Dia mengajarkan bahwa nikah pengikutaya hanya sah bila dilakukan oleh gurunya (Noce). Pengikut yang sudah menikah harus dinikahkan ulang oleh dirinya, dan boleh menidurinya.

Aliran La dan Lu, gurunya tidak teridentifikasi namanya. Di antara ajarannya adalah bahwa calon pasangan pengantin yang batal menikah karena salah seorang di antaranya meninggal dunia, pernikahannya dapat dilaksanakan atas nama yang meninggal tetapi diwakili oleh orang tuannya atau kerabatnya.

Aliran guru ibu, tokohnya tidak teridentifikasi antara ajarannya adalah ibu yang sebenarnya adalah guru. Karena itu, kewajiban kepada guru lebih utama dari pada kewajiban pada ibu kandung.

Terhadap aliran bermasalah $\mathrm{di}$ atas tampaknya ada yang bermasalah dari segi akidah seperti Ahmadiyah, dari segi syariah seperti syiah jafariyah, Noce, dan La dan Lu, dan adapula yang dari segi akhlak seperti guru ibu.

Informasi tentang aliran bermasalah di Indonesia telah meluas di masyarakat, melalui pemberitaan media. Melalui penayangan di media itu, masyarakat mengetahui bahwa ada aliran keagamaan tertentu adalah bermasalah. Informasi tentang aliran bermasalah di lokasi penelitian, komunitas madrasah memperolehnya dari media lokal, misalnya dari Koran Post Maluku Utara, RRI Ternate, TV Lokal, informasi lisan dari teman sejawat yang sempat melihat di media ataupun yang terlibat dalam diskusi yang diprakarsai MUI dan Kemenag Provinsi/Kota serperti kasus Syiah Jafariah dan Ahmadiyah. Hal itu diungkapkan oleh Drs. Yusuf Pellu (guru akidah akhlak dan quran hadits) beserta beberapa guru lainnya saat berbincang-bincang dengan mereka di ruang perpustakaan MAN Model Ternate tanggal 10 Juli 2012.

Mencermati upaya penanggulangan aliran bermasalah di madrasah, sesuai dengan kerangka teori yang dibangun maka ada dua perspektif yang dilakukan, yaitu pertama, keinginan melakukan, kedua, telah dan sedang melakukan upaya penanggulangan.

Hasil penelitian lapangan mengungkapkan bahwa upaya penanggulangan aliran bermasalah di madrasah, dilakukan secara kurikuler maupun extrakurikuler, namun penanggulangannya lebih bersifat prefentif. Penanggulangan melalui Kurikulum. Berkaitan dengan upaya ini, beberapa guru diwawancarai berkaitan upaya mereka memberikan pencerahan pada siswanya agar tidak terlibat dalam aliran bermasalah yang ada. 
Drs. Yusuf Pellu (Guru Aqidah Akhlak dan Quran Hadits), mengungkapkan bahwa pemuatan topik aliran bermasalah dalam kegiatan pembelajaran, tidak disajikan dalam pokok atau sub bahasan, karena setiap bidang studi telah tersusun sillabinya. Tema bermasalah tidak di masukkan disana karena secara kasat mata tidak ada juga siswa kita diketahui menganut faham bermasalah tertentu. Namun sebagai langkah antisipasi, kita memberi penjelasan tambahan bila ada materi bahasan berkaitan faham keagamaan dan mewantiwanti siswa agar tidak mudah tertarik bila ada yang mengajak untuk bergabung dalam faham keagamaan tertentu. Karena itu diperlukan pengetahuan yang kuat oleh seorang guru.(wawancara tanggal 11/7/2012).

Drs. Lukman(GuruSKIMANModel Ternate), mengungkapkan bahwa "menjadikanaliran bermasalah sebagai pokok atau sub bahasan, belum dilakukan, materi berkaitan bidang studi SKI sudah terbakukan. Jadi yang dilakukan adalah pengembangan dan memberikan contoh. Di dalam SKI ada materi tentang mazhab-mazhab, perkembangan Islam di Indonesia. Pada materimateri itulah faham-faham bermasalah disisipkan sebagai pengembangan jam pelajaran, contoh diikuti penjelasan yang relevan dengan konteksnya. Salah satu tujuannya agar siswa memiliki pengayaan dan pencerahan (wawancara 16/7/2012).

Beberapa Guru bidang studi lainnya, melakukan penanggulangan melalui extra kurikuler. Kegiatan pencerahan keagamaan terhadap siswa dan komunitas madrasah menjadi program madrasah dalam berbagai bentuk kegiatan. Beberapa kegiatan sering melibatkan masyarakat didalamnya, bahkan menjadikan masyarakat sebagai sasaran kegiatan.

Di antara kegiatan pencerahan yang dilakukan adalah: Di internal adrasah, pada program OSIS. ada beberapa kegiatan yang dilakukan, di antaranya: pembacaan doa oleh siswa setiap apel pagi dilakukan secara bergilir, ada ceramah berdimensi agama oleh guru ataupun siswa selama lima menit (kulim), Shalat jamaah, jadwal perkelas. Peringatan hari besar Islam, Shalat Dhuha, ceramah agama setiap selesai semester (Siti Magfirah, wawancara , 16/7/2012).

Drs. Syamsuddin, M.Pdi menambahkan ada kegiatan kajian berkaitan momen tertentu, seminar dan ceramah melibatkan guru dan orang luar. (wawancara, 14 juli 2012).

Kegiatan external yang melibatkan masyarakat. Kegiatan itu adalah "studi wisata keagamaan " dengan melakukan simulasi tata cara pengurusan jenazah, dilakukan ditempat rekreasi "sulamadaha". Kegiatannya melibatkan masyarakat setempat dan siswa MAN Model Ternate sebagai pameran aksi. Sedangkan tutornya adalah guru MAN Model Temate. Menurut Yusuf Pellu kegiatan ini sudah dua kali dilakukan dalam dua tahun terakhir (wawancara, 11/7/2012).

Kegiatan masyarakat yang melibatkan siswa. Menurut Syamsuddin, (Guru Fiqhi/Wakamad Kesiswaan) bahwa kelompok kajian Wahdah Islamiyah, telah melakukan kajian ilmiah dan tablig akbar sering mengundang MAN Model Temate untuk diikutkan dalam kegiatan tersebut, bila acaranya diluar jam belajar, sering saya mengutus siswa yang berminat. Hal serupa diungkap juga oleh Dra. Hadijah (Guru Sosiologi/BK) bahwa STAIN Ternate dengan wadah "Rohis" nya sering melakukan kajian islamiah dan meminta keikutsertaan siswa MAN Model Ternate. Bahkan Ibu Hadijah sering jadi Narasumber. (wawancara, 14/7/2012).

Terhadap kegiatan tersebut, walaupun secara eksplisit tidak menyebutkan sebagai upaya penanggulangan aliran bermasalah, tetapi secara implisit memiliki dimensi kearah itu karena memberi pencerahan dan pengayaan pada siswa dalam memahami dan meng kcntekstualkan ajaran agamanya. Hal itu dapat berimplikasi pada pembentengan terhadap faham dan nilai yang berbeda atau bertentangan dengan yang di fahaminya selama ini.

\section{Respon Komunitas Madrasah terhadap Aliran Bermasalah}

Para guru dan komunitas madrasah lainnya menilai bahwa aliran bermasalah yang ada dalam masyarakat, banyak menunjukkan ajaran yang aneh-aneh, berbeda dengan yang umum dilakukan oleh masyarakat, bahkan yang kita pahami.

Keanehan itu terkait aqidah, ibadah, akhlak dan sosial. Dicontohkan oleh Dra Hadijah Suaib (Guru Sosiologi/BK MAN Model Ternate), Ahmadiyah yang mengklaim Gulam Ahmad 
sebagai Nabi mereka sesudah Nabi Muhammad, Syi'ah Jafariah yang menganggap tidak sah jamaah kalau bukan mereka yang memimpin, Naceh yang menghalalkan zina oleh guru pada anggotanya dan aliran lainnya yang bertentangan dengan nilai-nilai kesusilaan (wawancara 11/7/2011 di ruang Guru MAN Model Temate).

Contoh-contoh yang disebutkan oleh Ibu Hadijah, di iyakan oleh Guru-guru lainnya di ruangan itu. Di tambahkan Yusuf Pellu, mengantisifasi ajaran-ajaran bermasalah semacam di atas, perlu dilakukan penguatan nilai-nilai agama di madrasah oleh semua guru, sesuai bidang studi masing-masing.

\section{Respon Masyarakat Terhadap Upaya Penanggulangan oleh Madrasah}

Penanggulangan aliran bermasalah yang dilakukan oleh madrasah, bukanlah semata sebagai upaya independensi madrasah dalam kepedulian terhadap siswanya, tetapi menjadi bagian dari program Kementerian Agama Provinsi Maluku Utara sejak tahun 2010.

Kasi Mapenda Drs. Sarbin mengemukakan hal itu sebagai berikut: (1) Dihimbau kepada kepala madrasah agar waspada terhadap pengembangan aliran bermasalah; (2) Me!akukan koordinasi dengan tokoh agama setempat; (3) Melaporkan ke Kanwil Agama tentang perkembangan kegiatan yang dilakukan; (4) Dapat dilakukan dalam berbagai kesempatan di madrasah, (wawancara, 10/7/2012)

Upaya pencegahan aliran bermasalah di MAN Model Ternate diresponi secara variatif oleh masyarakat, diantaranya: (1) Kanwil Kementerian Agama pada satu sisi melihatnya sebagai awal yang baik, walaupun belum dilakukan secara terkoordinasi dengan pihak Kanwil Kemenag Maluku Utara. Padahal dengan koordinasi itu, dapat menyusun program yang lebih konkrit dengan melibatkan MA lain dalam KKM sehingga terbangun visi bersama dalam menyikapi aliran bermasalah di Ternate; (2) Drs. Sulmin A. Kadir (Pengurus NU Kota Ternate) juga menyikapi upaya madrasah itu sebagai awal yang baik. Tetapi madrasah perlu mengembangkan program lanjutan di keluarga dengan mengajak orang tua siswa berperan aktif mengawasi dan mengarahkan anaknya dengan memberi kegiatan yang positif dan produktif yang baik bagi keluarga. Kegiatan dilakukan secara terkoordinasi antara madrasah dengan orang tua siswa. Waktu siswa akan terserap dalam kegiatan positif. (Wawancara, 20 Juli 2012); (3) Menurut Dr. Jafar Assagaf (ketua Majelis Fatwa MUI Provinsi Maluku Utara/Unsur Al Khairat) mengatakan upaya madrasah menanggulangi aliran bermasalah belum optimal dan belum memberi dampak kuat terhadap siswa, apalagi untuk jangka panjang. Ada baiknya pihak madrasah mengoptimalkan pembelajaran extrakurikuler dengan menerapkan pendidikan besik keagamaan dalam bentuk kajian literasi. Kajian itu menggunakan kitab tertentu, dilakukan secara berkesinambungan. Penerapannya ala pesantren. Dampaknya siswa akan memiliki pondasi pemahaman keagamaan yang kuat, sehingga tidak mudah terpengaruh terhadap faham-faham keagamaan yang muncul kemudian. Terhadap masyarakat, diharapkan melakukan hal serupa dengan mengaktifkan pengajian kitab secara rutin di mesjid-mesjid, majelis ta'lim, dan lembagalembaga. (wawancara, 18/7/2012).

Respon masyarakat tersebut mencerminkan besarnya harapan masyarakat terhadap madrasah untuk mengambil peran nyata dalam penanggulangan aliran bermasalah di masyarakat yang di mulai dari komunitas madrasah itu sendiri.

\section{PENUTUP}

Penanggulangan aliran bermasalah menjadi kewajiban semua elemen dalam masyarakat. Madrasah sebagai bagian tak terpisahkan dari masyarakat, memiliki tanggung jawab tentang hal tersebut setidaknya terhadap komunitas dalam lingkungannya.

Munculnya aliran bermasalah di masyarakat di lokasi penelitian, ada yang datang dari luar dan ada pula yang muncul dari dalam. Hal itu tidak terlepas oleh pengaruh sosio kultural masyarakat bersangkutan.

Aliran bermasalah yang teridentifikasi disikapi madrasah sebagai sebuah fenomena keberagamaan masyarakat yang harus di tangkal agar tidak merasuki tatanan keberagamaan siswa. Segenap elemen madrasah melakukan upaya pencegahan. Bidang studi agama atau pelajaaran agama yang diberikan kepada siswa selama ini baik secara intra maupun ekstra kurikuler merupakan hal mendasar 
dalam upaya penanggulangan aliran bermasalah secara prefentif, yang dilakukan oleh guru umumnya secara parsial hanya tergantung pada inisiatif guru bidang studi tertentu. Implikasinya terhadap siswa hanya menjadi terapi sesaat yang kurang berdampak dalam membangun pondasi keberagamaan siswa dalam jangka panjang. Karena itu perlu dilanjutkan dan ditingkatkan pelaksanaannya bahkan dapat dijadikan cikal bakal dari upaya penaggulangan secara nyata dan terprogram di masyarakat secara luas.

\section{UCAPAN TERIMA KASIH}

Terima kasih penulis sampaikan pada Balai Penelitian dan Pengembangan Agama Makassar yang telah mengamanahkan untuk melakukan penelitian di Kota Ternate. Kepada Kepala MAN Model Ternate, para guru, dan informan dari berbagai kalangan yang telah memberi sejumlah informasi berkaitan penelitian ini. Kepada Dewan Redaksi Jurnal Al-Qalam yang bersedia menerbitkan tulisan ini.

\section{DAFTAR PUSTAKA}

Badan Litbang dan Diklat. 2010. Rencana Strategis Badan Litbang dan Diklat Kementerian
Agama 2010-2014.

Bagir, Haidar. 2012. Aliran Sesat atau Aliran Bermasalah. http://www.muhsinlabib.com/ analisis/alirdn-sesat-aliran-bennasalah. diakses tanggal 5 januari 2012.

van Bruinessen, Martin. 1992. Gerakan Bermasalah di Kalangan Umat Islam Indonesia: Latar Belakang Sosial budaya. Ulumul Quran Vol. Ill No. 1.

Burhanuddin, Nunu. Tipologi Gerakan Bermasalah di Kalangan Umat Islam Indonesia: Analisis Sosiologis dan Fungsional (Makalah).

Kemenag RI. 2011. Penanganan Aliran Dan Gerakan Keagamaan Bermasalah Di Indonesia, Puslitbang Kehidupan Keagamaan.

Mas'ud, Abdurrahman. 2009. Menyikapi Keberadaan Aliran Bermasalah. Dialog Jurnal Penelitian dan Kajian Keagamaan No. 68 Tahun XXXII, November 2009.

Maleong, L. J. 2008. Metodologi Penelitian Kualitatif Cet. 25. Bandung: Rosdakarya.

Muhajir, Noeng. 1994. Metode Penelitian Kualitatif. Yogyakarta: Rakesarasen.

Peraturan Pemerintah Nomor 55 Tahun 2007.

Singarimbun, Masri, dkk. 1987. Metode Penelitian Survai, Cet. IV. Jakarta: LP3ES.

Zuchdi, Darmayati. 2009. Humanisasi Pendidikan. Jakarta: Bumi Aksara. 